\title{
Numerical Analysis on Chaos Synchronization in Semiconductor Lasers Subject to a Common Drive Signal
}

\author{
Isao Oowada Non-member (i.oowada@gmail.co.jp) \\ Toru Yamamoto Non-member (t.mountainbook.no7@gmail.com) \\ Atsushi Uchida Member (a-uchida@es.takushoku-u.ac.jp) \\ Sigeru Yoshimori Member (yosimori@es.takushoku-u.ac.jp) \\ Kazuyuki Yoshimura Non-member (kazuyuki@cslab.kecl.ntt.co.jp) \\ Jun Muramatsu Non-member（pure@cslab.kecl.ntt.co.jp) \\ Shin-itiro Goto Non-member (sgoto@cslab.kecl.ntt.co.jp) \\ Peter Davis Non-member (davis@cslab.kecl.ntt.co.jp)
}

Keywords : chaos, synchronization, semiconductor laser, security, cryptography

Synchronization of chaos in lasers has attracted much interest from the point of view of potential applications in communications, such as optical secure communications and spread-spectrum communications $^{(1)(2)}$. In previously well studied applications of synchronized laser chaos to secure communications, a chaotic carrier is used to hide a data signal. In this type of application, high-quality synchronization of chaos in the transmitter and receiver lasers is required to recover the hidden data. It is also possible that synchronized chaotic lasers could be used for generating correlated random signals to obtain secret communication keys which are secure in the sense of information theoretic security ${ }^{(3)(4)}$. Optimally correlated sources for key generation and their key generation capacity under sampling attack have been analyzed $\mathrm{in}^{(4)}$. In this type of application it is necessary to achieve a strong correlation between the outputs of two remote chaotic lasers driven by one common driving signal, while the correlation between drive signal and response laser output should be undetectable so that an eavesdropper cannot predict the response signal even if she can receive the same driving signal.

We numerically observe chaos synchronization of two semiconductor lasers commonly driven by a chaotic semiconductor laser subject to optical feedback (Fig. 1). We considered a numerical model for the synchronization of semiconductor lasers. We used three sets of the Lang-Kobayashi equations for semiconductor lasers subject to optical feedback and injection. We used the fourth-order Runge-Kutta method in our

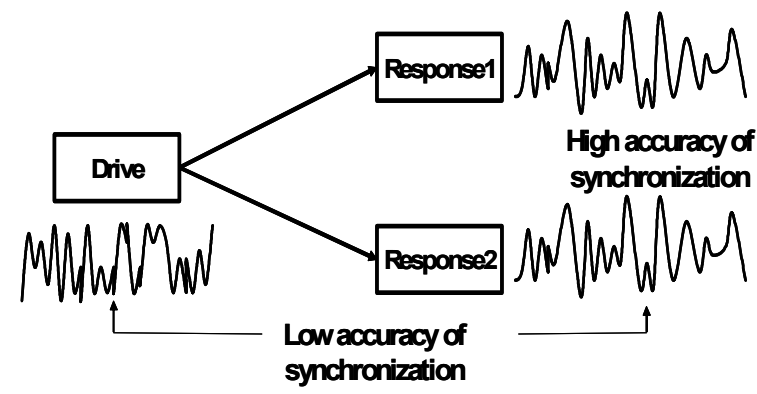

Fig. 1. Schematics of chaos synchronization in semiconductor lasers subject to a common chaotic drive signal

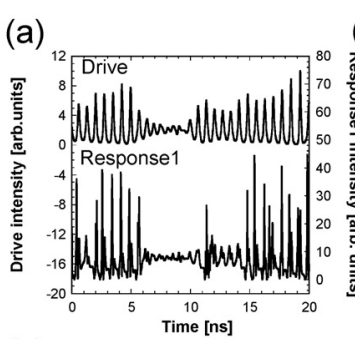

(c)
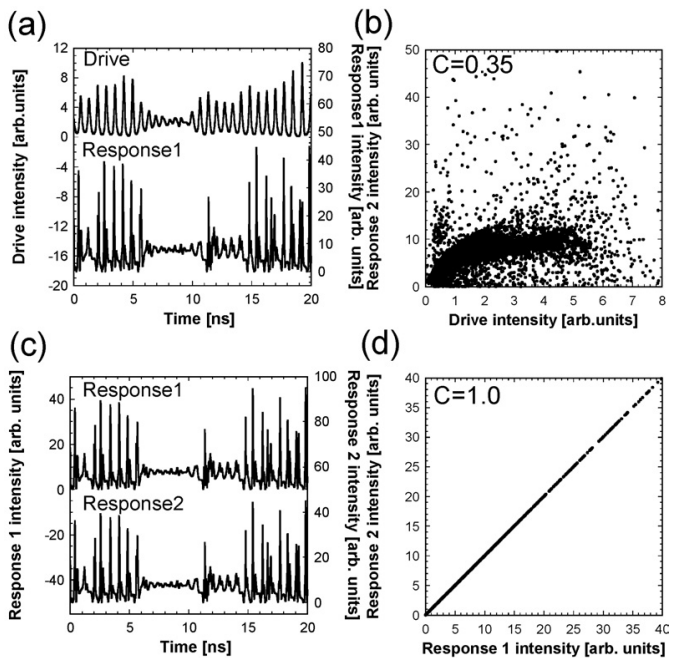

(d)

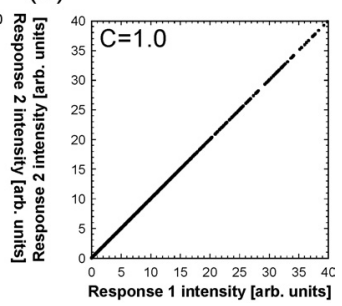

Fig. 2. Numerical result of temporal waveforms and corresponding correlation plots for (a), (b) Drive and Response 1, (c), (d) Response 1 and Response 2. The cross correlation values are (b) 0.35 , (d) 1.0

numerical calculation. We numerically obtained temporal waveforms, correlation plots in Fig. 2. Under condition that the relaxation oscillation frequency is matched between the two response lasers, but mismatched between the drive and the two response lasers, we show that it is possible to observe strongly correlated synchronization between the two response lasers even when the correlation between the drive and response lasers is low.

\section{References}

(1) G. D. VanWiggeren and R. Roy : "Communication with chaotic lasers", Science Vol.279, pp.1198-1200 (1998)

(2) A. Argyris, D. Syvridis, L. Larger, V. Annovazzi-Lodi, P. Colet, I. Fischer, J. Garcia-Ojalvo, C. R. Mirasso, L. Pesquera, and K. A. Shore "Chaos-based communications at high bit rates using commercial fiber-optic links", Nature, Vol.438, pp.343-346 (2005)

(3) U. M. Maurer : "Secret key agreement by public discussion from common information”, IEEE Trans. Information Theory, Vol.39, pp.733-742 (1993)

(4) J. Muramatsu, K. Yoshimura, K. Arai, and P. Davis : "Secret key capacity for optimally correlated sources under sampling attack", IEEE Trans. Information Theory, Vol.52, pp.5140-5151 (2006) 


\section{半導体レーザを用いた共通信号入力によるカオス同期の数值解析}

$\begin{array}{llll}\text { 非会員 大和田 功* } & \text { 非会員 山本 徹* } \\ \text { 正 員 内田 淳史* } & \text { 正員 } \text { 吉森 茂* }^{*} \text { 非会員 吉村 和之** } & \text { 非会員 村松 純** } \\ \text { 非会員 後藤振一郎** } & \text { 非会員 ピーター ディビス** }\end{array}$

\section{Numerical Analysis on Chaos Synchronization in Semiconductor Lasers Subject to a Common Drive Signal \\ Isao Oowada*, Non-member, Toru Yamamoto*, Non-member, Atsushi Uchida*, Member,} Shigeru Yoshimori*, Member, Kazuyuki Yoshimura**, Non-member, Jun Muramatsu**, Non-member, Shin-itiro Goto**, Non-member, Peter Davis** ${ }^{*}$, Non-member

We numerically observe chaos synchronization of two semiconductor lasers commonly driven by a chaotic semiconductor laser subject to optical feedback. We observe strongly correlated chaos synchronization between the two response lasers even when the correlation between the drive and response lasers is low. We show that the cross correlation between the two responses is larger than that between drive and responses over a wide parameter region.

キーワード : カオス, 同期, 半導体レーザ, セキュリティ, 暗号

Keywords : chaos, synchronization, semiconductor laser, security, cryptography

\section{1. まえがき}

近年通信ネットワークの発達に伴い，外部からの盗聴を 防御する高度な情報セキュリティ技術が必要不可欠となり つつある。従来の情報セキュリティ技術は計算量複雑性に 基づく暗号方式が主流であるが，近年新たな情報セキュリ ティ方式の 1 つとして, 情報理論的に安全な相関乱数暗号 方式が提案されている(1)。これは盗聴者を含むす心゙てのユー ザが相関のある乱数列を共有する状況から，安全な暗号鍵 を生成する方式である。またこの枠組みにおいて, 最適な 相関乱数の性質が明らかにされている(2)。

相関乱数暗号方式の要素技術として，共通信号入力によ るカオス同期が重要となる( ${ }^{(3)}$ 。そのモデル図を Figure 1 に示 す。駆動用レーザ（Drive）からのカオス信号が 2 つの同期 用レーザ (Response) に一方向に注入される場合を考える。 この時 2 つの Response レーザ間のカオス時間波形は高い相

* 拓殖大学工学部電子システム工学科

干193-0985＼cjkstart東京都八王子市館町 815-1

Department of Electronics and Computer Systems, Takushoku University

815-1 Tatemachi, Hachiouji, Tokyo 193-0985

** NTTコミュニケーション科学基礎研究所 日本電信電話(株) 干619-0237 京都府相楽郡精華町光台 2-4

NTT Communication Science Laboratories, NTT Corporation

2-4 Hikaridai, Seika-cho, Soraku-gun, Kyoto 619-0237

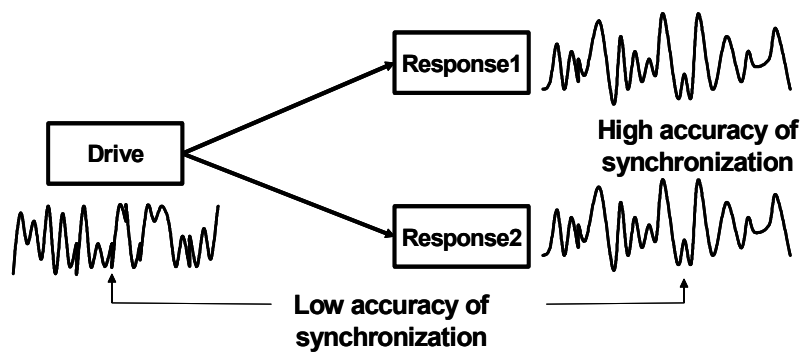

Fig. 1. Schematics of chaos synchronization in semiconductor lasers subject to a common chaotic drive signal.

関を示すが, Drive レーザと Response レーザ間のカオス時間 波形は低い相関を示すことが，応用上重要な性質である(3)。

Figure 1 に示すような同期方式は, 一般化カオス同期(4)や ノイズ同期 ${ }^{(5)}$ として物理的興味に基づく基礎研究が進展し ている。一般化カオス同期は $\mathrm{He}-\mathrm{Ne} レ ー サ ゙(6) や ~ N d: \mathrm{YVO}_{4}$ マ イクロチップレーザ(7)で観測されているものの, 光通信で主 流となる半導体レーザでの観測は未だ行われていなかっ た。我々は近年, 半導体レーザを用いた共通信号入力によ るカオス同期実験を行い，2 つの Response 間のカオス時間 波形は高い相関を示すが, Drive と Response 間のカオス時間 波形は低い相関を示すことを実験的に観測した ${ }^{(3)}$ 。 
そこで本研究では，半導体レーザを用いた共通信号入力 によるカオス同期の数值解析を行い， 2 つの Response レー ザ間の相関と Drive-Response レーザ間の相関を定量的に調 查することを目的とする。

\section{2. モ デル}

まず始めに，一方向結合された 3 つの半導体レーザにお いてカオス同期が達成される条件を数值解析により調査し た。光注入型カオス同期法のモデル図を Fig. 2 に示す。Drive は外部鏡 $\mathrm{M}$ からの時間遅延した戻り光によりカオスが発生 するが，2つの Response は自分自身の戻り光を持たず，同 期のための注入光のみが入射されると仮定する。ここで Drive で発生したカオス光を, 戻り光を持たない二つの Response に注入する。この時 $k_{i n j 1}$ は Drive から Response1 の注入光量を表し， $k_{i n j 2}$ は Drive から Response 2 への注入光 量を表す。また注入光の伝搬時間遅延をそれぞれ $\tau_{i n j 1}, \tau_{i n j 2}$ と表す。また光アイソレータ（ISO）により一方向結合を達 成させた。このようなモデルを考え, 以下に Lang-Kobayashi 方程式に基づくレート方程式を示す ${ }^{\left({ }^{(8)}\right.}$ 。

Drive レーザ

$$
\begin{aligned}
& \frac{d E_{d}(t)}{d t}=\frac{1}{2}\left[G_{N}\left(N_{d}(t)-N_{0}\right)-\frac{1}{\tau_{\mathrm{p}}}\right] E_{d}(t)+\frac{k_{d}}{\tau_{i n}} E_{d}(t-\tau) \cos \left(\theta_{d}(t)\right) \cdots \\
& \frac{d \varphi_{d}(t)}{d t}=\frac{\alpha}{2} G_{N}\left(N_{d}(t)-N_{t h}\right)-\frac{k_{d}}{\tau_{i n}} \frac{E_{d}(t-\tau)}{E_{d}(t)} \sin \left(\theta_{d}(t)\right) \\
& \frac{d N_{d}(t)}{d t}=J_{d}-\frac{N_{d}(t)}{\tau_{s}}-G_{N}\left(N_{d}(t)-N_{0}\right)\left|E_{d}(t)\right|^{2} \ldots \ldots \ldots \\
& \theta_{d}(t)=\omega_{d} \tau+\phi_{d}(t)-\phi_{d}(t-\tau)
\end{aligned}
$$

Response1 レーザ

$$
\begin{aligned}
& \frac{d E_{r 1}(t)}{d t}=\frac{1}{2}\left[G_{N}\left(N_{r 1}(t)-N_{0}\right)-\frac{1}{\tau_{\mathrm{p}}}\right] E_{r 1}(t)+\frac{k_{i j i 1}}{\tau_{i n}} E_{d}\left(t-\tau_{i j i 1}\right) \cos \left(\theta_{r 1}(t)\right) \\
& \frac{d \varphi_{r 1}(t)}{d t}=\frac{\alpha}{2} G_{N}\left(N_{r 1}(t)-N_{t h}\right)-\frac{k_{i n j 1}}{\tau_{i n}} \frac{E_{d}\left(t-\tau_{i n j 1}\right)}{E_{r 1}(t)} \sin \left(\theta_{r 1}(t)\right) \\
& \frac{d N_{r 1}(t)}{d t}=J_{r 1}-\frac{N_{r 1}(t)}{\tau_{s}}-G_{N}\left(N_{r 1}(t)-N_{0}\right)\left|E_{r 1}(t)\right|^{2} \\
& \theta_{r 1}(t)=-\Delta \omega t+\omega_{d} \tau_{i n j 1}+\phi_{r 1}(t)-\phi_{d}\left(t-\tau_{i n j 1}\right)
\end{aligned}
$$

Response2 レーザ

$$
\begin{aligned}
& \frac{d E_{r 2}(t)}{d t}=\frac{1}{2}\left[G_{N}\left(N_{r 2}(t)-N_{0}\right)-\frac{1}{\tau_{\mathrm{p}}}\right] E_{r 2}(t)+\frac{k_{i n j 2}}{\tau_{i n}} E_{d}\left(t-\tau_{i j i 2}\right) \cos \left(\theta_{r 2}(t)\right) \cdots \\
& \frac{d \varphi_{r 2}(t)}{d t}=\frac{\alpha}{2} G_{N}\left(N_{r 2}(t)-N_{t h}\right)-\frac{k_{i n j 2}}{\tau_{i n}} \frac{E_{d}\left(t-\tau_{i n j 2}\right)}{E_{r 2}(t)} \sin \left(\theta_{r 2}(t)\right) \cdots \\
& \frac{d N_{r 2}(t)}{d t}=J_{r 2}-\frac{N_{r 2}(t)}{\tau_{s}}-G_{N}\left(N_{r 2}(t)-N_{0}\right)\left|E_{r 2}(t)\right|^{2} \cdots \cdots \\
& \theta_{r 2}(t)=-\Delta \omega t+\omega_{d} \tau_{i n j 2}+\phi_{r 2}(t)-\phi_{d}\left(t-\tau_{i n j 2}\right) \ldots \ldots \ldots \ldots \ldots
\end{aligned}
$$

ここで, $E(t)$ はレーザ内部の光電場の振幅, $\varphi(t)$ はレー

\begin{tabular}{|c|c|c|}
\hline Symbol & Parameter & Value \\
\hline$G_{N}$ & Gain coefficient & $8.4 \times 10^{-13} \mathrm{~m}^{3} \mathrm{~s}^{-1}$ \\
\hline$\alpha$ & $\begin{array}{l}\text { Linewidth enhancement } \\
\text { factor }\end{array}$ & 3.0 \\
\hline$r_{2}$ & Facet reflectivity & 0.556 \\
\hline$r_{3}$ & $\begin{array}{l}\text { Reflectivity of external } \\
\text { mirror }\end{array}$ & 0.0060 \\
\hline$N_{0}$ & $\begin{array}{c}\text { Carrier density at } \\
\text { transparency }\end{array}$ & $1.400 \times 10^{24} \mathrm{~m}^{-3}$ \\
\hline$N_{t h}$ & $\begin{array}{l}\text { Carrier density at } \\
\text { threshold }\end{array}$ & $2.018 \times 10^{24} \mathrm{~m}^{-3}$ \\
\hline$\tau_{s}$ & Carrier lifetime & $2.04 \mathrm{ps}$ \\
\hline$\tau_{p}$ & Photon lifetime & $1.927 \mathrm{ps}$ \\
\hline$\tau_{\text {in }}$ & $\begin{array}{l}\text { Roundtrip time in laser } \\
\text { cavity }\end{array}$ & $8.0 \mathrm{ps}$ \\
\hline$\tau$ & $\begin{array}{c}\text { Roundtrip time in } \\
\text { external cavity }\end{array}$ & $4.0 \mathrm{~ns}$ \\
\hline$\tau_{i n j 1,2}$ & $\begin{array}{l}\text { Transmission time for } \\
\text { injection }\end{array}$ & $4.0 \mathrm{~ns}$ \\
\hline$J_{d} / J_{t h}$ & $\begin{array}{l}\text { Normalized injection } \\
\text { current of drive }\end{array}$ & 1.11 \\
\hline$J_{r 1} / J_{t h}$ & $\begin{array}{l}\text { Normalized injection } \\
\text { current of response } 1\end{array}$ & 1.36 \\
\hline$J_{r 2} / J_{t h}$ & $\begin{array}{l}\text { Normalized injection } \\
\text { current of response } 2\end{array}$ & 1.36 \\
\hline$\lambda_{d}$ & $\begin{array}{l}\text { Optical wavelength of } \\
\text { drive }\end{array}$ & $1546 \mathrm{~nm}$ \\
\hline$k_{d}$ & $\begin{array}{c}\text { Feedback coefficient of } \\
\text { drive }\end{array}$ & 0.0075 \\
\hline$k_{i n j 1} / k_{d}$ & $\begin{array}{l}\text { Injection coefficient of } \\
\text { response } 1\end{array}$ & 40.0 \\
\hline$k_{i n j 2} / k_{d}$ & $\begin{array}{l}\text { Injection coefficient of } \\
\text { response } 2\end{array}$ & 40.0 \\
\hline$\Delta f=\Delta \omega / 2 \pi$ & $\begin{array}{c}\text { Optical frequency } \\
\text { detuning }\end{array}$ & $-2.5 \mathrm{GHz}$ \\
\hline
\end{tabular}
ザ内部の光電場の位相, $N(t)$ はキャリア密度, $\theta(t)$ は位相 差, 下付き文字の $d, r 1, r 2$ はそれぞれDrive レーザ, Response 1 レーザ, Response2 レーザを表す。 $G_{N}$ は利得係数, $N_{0}$ は光 透過時のキャリア密度, $N_{t h}=N_{0}+1 /\left(G_{N} \tau_{p}\right)$ はレーザ発振時

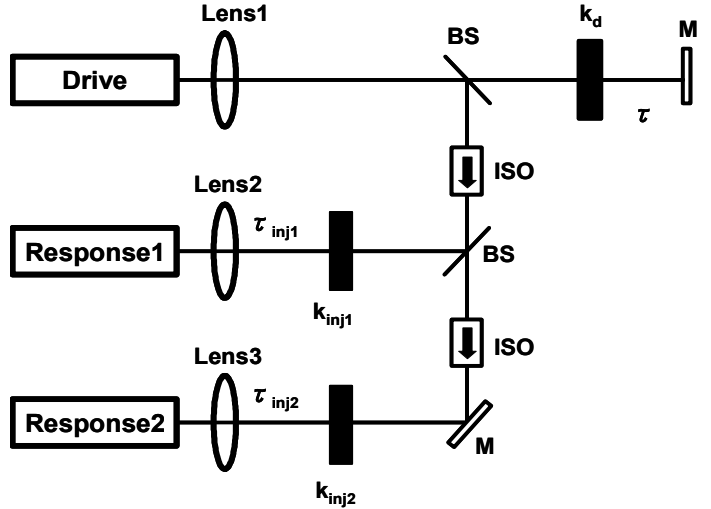

Fig. 2. Numerical model of chaos synchronization in two semiconductor lasers (Response 1 and 2) subject to a common chaotic semiconductor laser (Drive) with optical feedback.

Table 1. Parameter values for numerical simulation on chaos synchronization in semiconductor lasers subject to a common chaotic drive signal.

のキャリア密度, $\alpha$ は線幅増大係数, $k_{d}=\left(1-r_{2}{ }^{2}\right) r_{3} / r_{2}$ は Drive レーザの戻り光量, $r_{2}$ は内部鏡の反射率, $r_{3}$ は外部鏡 の反射率， $k_{i n j}$ は Drive から Response $へ$ の注入光量, $\tau_{s}$ と $\tau_{p}$ はそれぞれキャリア寿命と光子寿命, $\tau_{i n}=2 n l / c$ は内部共振 器一往復時間, $l$ は内部共振器長, $n$ は屈折率, $\tau=2 L / c$ は 外部共振器一往復時間, $L$ は外部共振器長, $\tau_{i n j}$ は Drive から Response までの光伝搬遅延時間, $J$ は注入電流, $J_{t h}=N_{t h} / \tau_{s}$ 
は注入電流のしきい值， $\omega_{d}=2 \pi c / \lambda_{d}$ は Drive レーザの発振 角周波数, $\lambda_{d}$ は Drive レーザの光波長, $\omega_{r}=2 \pi c / \lambda_{r}$ は Drive と結合していない時の Response の発振角周波数, $\Delta \omega=\omega_{d}-$ $\omega_{r}$ は無結合時における Drive と Response 間の光角周波数差, $\Delta f=\Delta \omega / 2 \pi$ は無結合時における Drive と Response 間の光周 波数差を表す。

\section{3. 半導体レーザにおけるカオス同期}

3 つのレーザパラメータが完全に一致し， $\tau=\tau_{i n j 1}=\tau_{i n j 2}$ お よび $k_{d}=k_{i n j 1}=k_{i n j 2}$ が満たされる時, Drive, Response1, Response2 のレート方程式は数学的に同一の方程式となる ため同期解が存在し, 電界振幅は $E_{d}(t)=E_{r 1}(t)=E_{r 2}(t)$ となる。 このように時間遅延の無い同期を完全同期（Perfect synchronization）と呼ぶ。一方で，3 つのレーザパラメータ が異なる条件でもインジェクションロッキング効果により Drive のカオス振動が Response で再生可能となる。この時の 電界振幅は $E_{d}(t)=E_{r 1}\left(t+\tau_{i n j 1}\right)=E_{r 2}\left(t+\tau_{i n j 2}\right)$ の関係を満た す。前述の完全同期とは異なりこの場合は Drive と Response の時間波形に時間遅延が存在しており，このようなカオス 同期をインジェクションロッキング型同期（Injection locking-type synchronization）と呼ぶ。以上より戻り光を有す る半導体レーザのカオス同期には 2 種類のカオス同期解が 存在している ${ }^{(8)}$ 。特に実験においてはパラメータ偏差に対し てロバストなインジェクションロッキング型同期が多く観 測されており，実用的である。そこで本研究ではインジェ クションロッキング型同期について詳細な調査を行った。

まず始めに一方向結合された 3 つの半導体レーザにおい て全てのパラメータ值を一致させ，インジェクションロッ キング型同期法を用いて，2 つの Response への注入光量

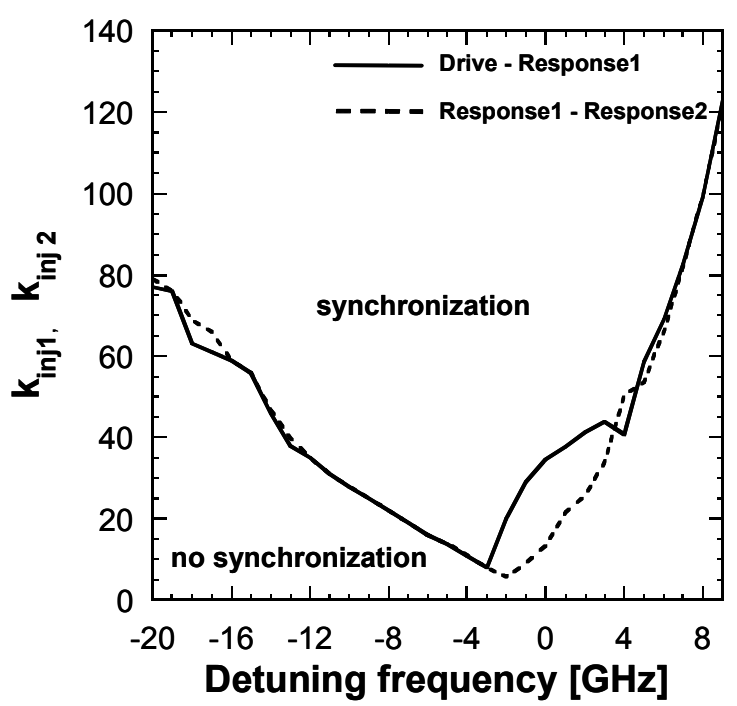

Fig. 3. Region of chaos synchronization as functions of injection coefficient and optical detuning frequency without coupling. Solid curve: synchronization between Drive and Response1. Dotted curve: synchronization between Response 1 and Response 2. $\left(k_{i n j 1}, k_{i n j 2}\right)$ を同時に変化させることでカオス同期を達成さ せた。また無結合時において Drive と Response に光周波数 差 $\Delta f$ が存在する場合を考え, $k_{i n j 1}, k_{i n j 2}$ と $\Delta f$ の変化に対する カオス同期の達成領域を数值解析により調査した。

カオス同期を定量的に評価するために, 2 つのカオス時間 波形に対する相互相関関数を用いた。相互相関関数 $C$ は以 下の式で定義される。

$$
c=\frac{\left\langle\left(I_{1}-\bar{I}_{1}\right)\left(I_{2}-\bar{I}_{2}\right)\right\rangle}{\sigma_{1} \sigma_{2}}
$$

ここで, $I_{1}, I_{2}$ は 2 つのカオス的レーザ強度の時間波形, $\bar{I}_{1}, \bar{I}_{2}$ は時間波形の平均值， $\sigma_{1} ， \sigma_{2}$ は時間波形の標準偏差， $<>$ は平均時間を表す。Cが 1 に近いほど相関が高いことを意味 している。

Figure 3 に $k_{i n j 1}, \quad k_{i n j 2}$ と $\Delta f$ の変化に対する Drive-Resposne1 間および Response1-Response2 間におけるカオス同期領域を 示す。ここでカオス同期領域は，2つの時間波形の相互相関 関数が 0.95 以上の場合の領域と定義した。Fig. 3 の実線およ び点線は相互相関関数が 0.95 の境界を示し, 上部がカオス 同期領域，下部が非同期領域に対応する。Fig. 3 を見ると無 結合時の光周波数差が-3.0 GHz のとき, 半導体レーザは最 小の注入光量でカオス同期することが分かる。この時イン ジェクションロッキング効果により Drive と Response の光 周波数も完全に一致していた。無結合時の光周波数差が $0.0 \mathrm{GHz}$ のときは最小の注入光量にならないが，これは $\alpha$ パ ラメータの影響によりインジェクションロッキングが負の 光周波数差 $\Delta f$ に対して起こりやすいためだと考えられる ${ }^{(9)}$ 。 つまり，無結合時において負の光周波数差を有している方 が，カオス同期が達成されやすいことが分かる。さらに Fig. 3 に示すカオス同期領域とインジェクションロッキング範 囲（光周波数が一致する範囲）はほぼ同一であり, カオス 同期時においては Drive と Response の光周波数も一致する ことが明らかとなった。

\section{4. 共通信号入カによるカオス同期の数值解析}

次に一方向結合された 3 つの半導体レーザにおいて, Drive-Response 間で異なるパラメータ值を用いることによ り, 共通信号入力によるカオス同期を実現した。本研究で は Drive-Response 間の緩和発振周波数を異なる值に設定し た。緩和発振周波数 $f_{r}$ は注入電流 $J$ に依存しており, 以下 の理論式で記述される。

$$
f_{r}=\frac{1}{2 \pi} \sqrt{\frac{G_{N} N_{t h}}{\tau_{s}}(J-1)}
$$

(14)式から求められた, 注入電流に対する緩和発振周波数 のグラフを Fig. 4 に示す。Fig. 4 より, 注入電流を Drive で $1.11 \mathrm{~J}_{\mathrm{th}}$, Response1 で $1.36 \mathrm{~J}_{\mathrm{th}}$, Response 2 で $1.36 \mathrm{~J}_{\mathrm{th}}$ と設定し た。この時の緩和発振周波数は Drive で $1.5 \mathrm{GHz}$, Response1 で $2.8 \mathrm{GHz}$, Response2 で $2.8 \mathrm{GHz}$ であった。2つの Response への注入光量は $k_{i n j 1}=k_{i n j 2}=40 k_{d}$ とし, また Drive と Response 

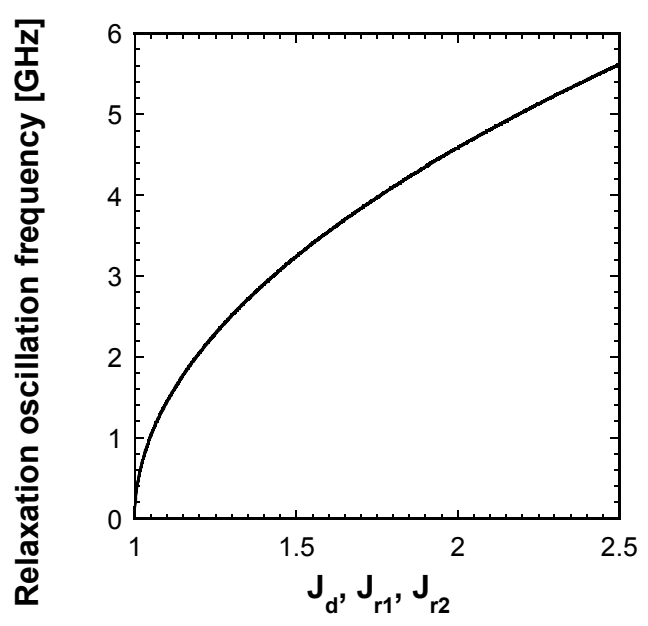

Fig. 4. Relaxation oscillation frequency as a function of injection current.

(a)
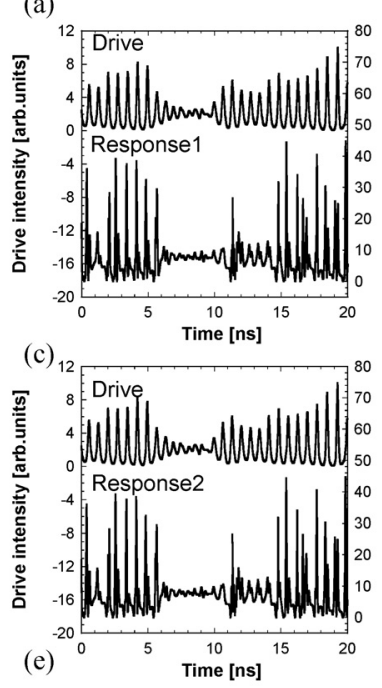

(b)
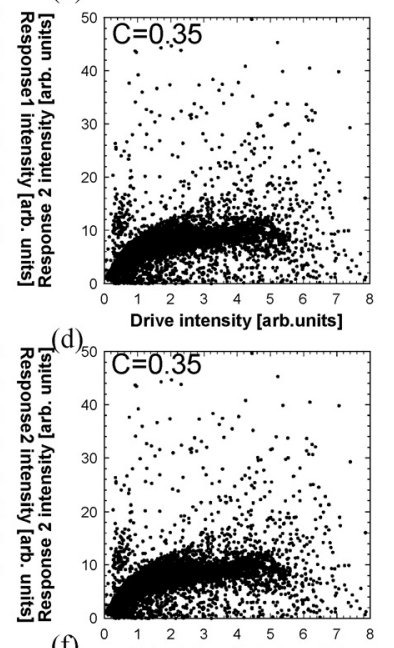

(f)
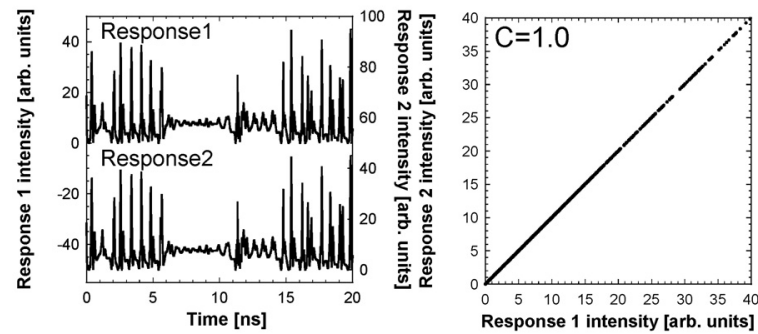

Fig. 5. Numerical result of temporal waveforms and corresponding correlation plots for (a), (b) Drive and Response 1, (c), (d) Drive and Response 2, and (e), (f) Response 1 and Response 2. The cross correlation values are (b) 0.35 , (d) 0.35 , and (f) 1.0 .

間の無結合時の光周波数差は $\Delta f=-2.5 \mathrm{GHz}$ に設定した。

この時の Drive-Response1 間, Drive-Response2 間および Response1-Response2 間の時間波形と相関図を Fig. 5 に示す。

Fig. 5(a)を見ると Drive と Response1 では同期しておらず, Drive-Response1 間の相互相関関数は 0.35 と低い相関を示し た (Fig. 5(b))。同様に Drive-Response2 間も同期せず，相互

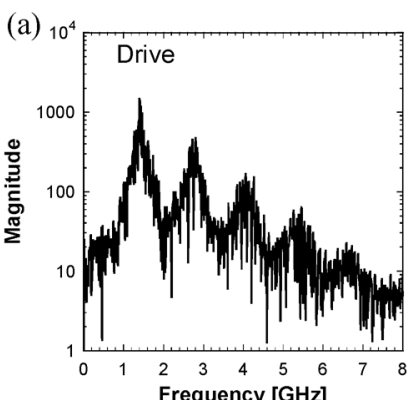

(b)

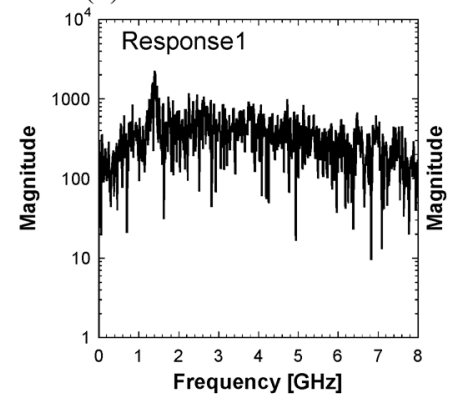

(c)

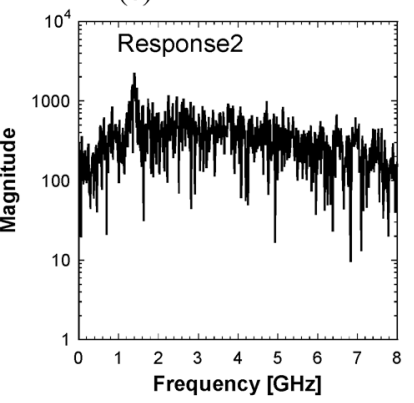

Fig. 6. Numerical result of RF spectra for (a) Drive, (b)

Response 1, and (c) Response 2.

相関関数は 0.35 と低い值を示した (Fig. 5(c), 5(d))。一方で, Response1- Response2 間では，時間波形は完全に同一の振動 をしている (Fig. 5(e))。相関図を見ても 45 度の直線であり， 相互相関関数も 1.0 と高い同期精度を示した (Fig. 5(f))。こ のように Response1-Response2 間の相関が Drive-Response 間 の相関よりも高いことが数值解析により明らかとなった。

この時の Drive, Response1, Response2 の RF スペクトル を Fig. 6 に示す。Drive と Response1 の RF スペクトル (Fig. 6(a)，(b))，および Drive と Response2 の RF スペクトル (Fig. 6(a)，(c)）の形状は全く一致していないことが分かる。一方 で, Response1 と Response2 の RF スペクトル (Fig. 6(b), (c)) を比較すると，ほぼ同一の形状をしていることが分かる。 これは Driveの緩和発振周波数を $1.5 \mathrm{GHz}$ に設定したのに対 し, Response 1 および Response 2 の緩和発振周波数を 2.8 $\mathrm{GHz}$ に設定したため, RF スペクトルの形状が異なっている と考えられる。つまり, Drive-Response 間で異なる緩和発振 周波数に設定することで Drive-Response 間の相関よりも Response1-Reponse2 間の相関を向上させることが可能であ ることが分かった。

\section{5. 共通信号入カによるカオス同期のパラメータ 依存性}

2 つの Response のパラメータ值の変化に対する Response1- Response2 間の相関および Drive-Response 間の相

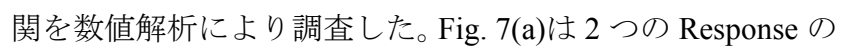
緩和発振周波数 $f_{r}$ を同時に変化させ， 3 つのレーザのうち 2 つのレーザ間の時間波形の相互相関関数をプロットした図

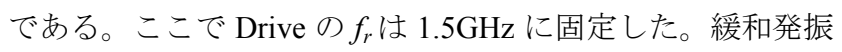
周波数 $f_{r}$ は(14)式に示寸ように注入電流 $\mathrm{J}$ に依存するため, $\mathrm{J}$ を変化させることで $f_{r}$ を変化させた。Fig. 7(a)より $f_{r}$ の変 
(a)

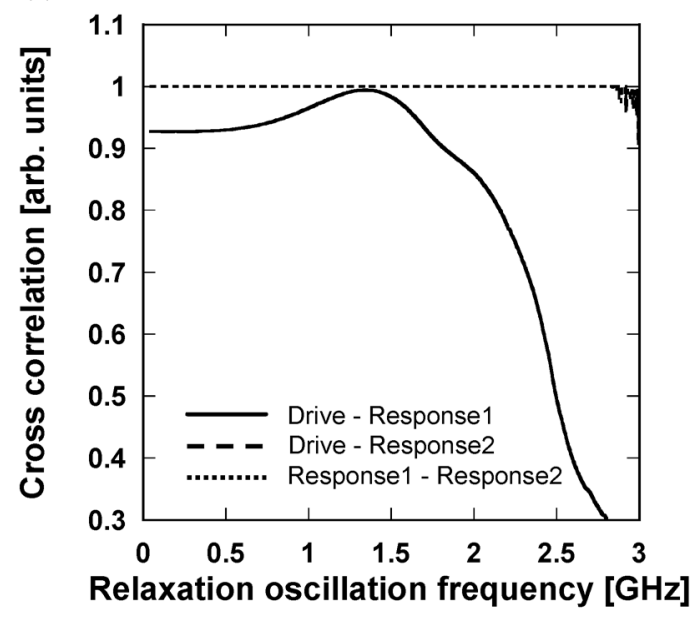

(b) 1

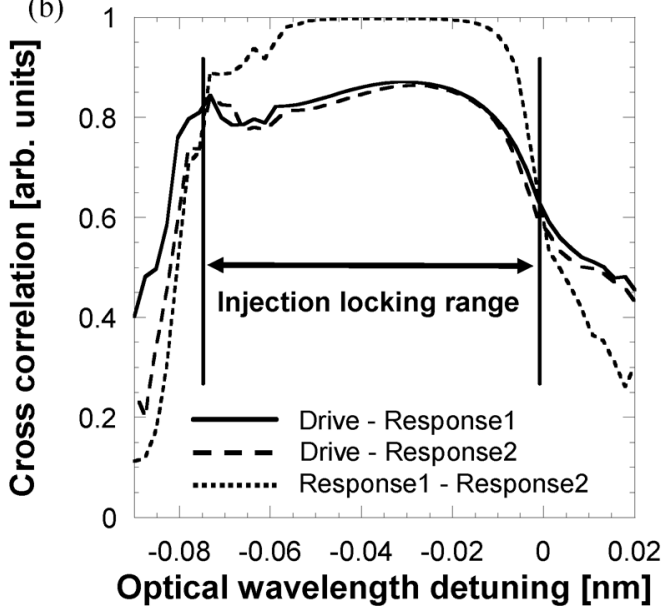

Fig. 7. Numerical result of the cross correlation between a pair of two lasers as a function of (a) the relaxation oscillation frequency of the Response lasers and (b) the optical wavelength detuning between Drive and Response lasers. Solid curve: Drive and Response 1, dashed curve: Drive and Response 2, dotted curve: Response 1 and Response 2. (a) The dashed curve overlaps with the solid curve.

化に対して Response1-Response2 間の相関が Drive-Response 間の相関よりも高いことが分かる。広範囲において Response1-Response2 間は高い相関を維持するが, Drive-Response 間の相関は低くなることが確認された。特に Drive-Response 間の緩和発振周波数をずらすことで, Response1-Response2 間と Drive-Response 間との相関差を大 きくすることが可能となる。

一方, Fig. 7(b)は Drive-Response 間の光波長差 $\Delta \lambda$ (光周波 数差 $\Delta f$, ここで $\Delta f[\mathrm{GHz}]=125 \Delta \lambda[\mathrm{nm}] ）$ を変化させ， $3 つ の$ レーザのうち 2 つのレーザ閒の時間波形の相互相関関数を プロットした図である。Fig. 7(b)より，光波長差が-0.074 $\sim-0.002 \mathrm{~nm}$ の範囲で Response1-Response2 間の相関が Drive-Response 間の相関より高いことが分かる。またこの範 囲は Drive と Response 間のインジェクションロッキング範 囲に対応している。つまり，インジェクションロッキング (a)
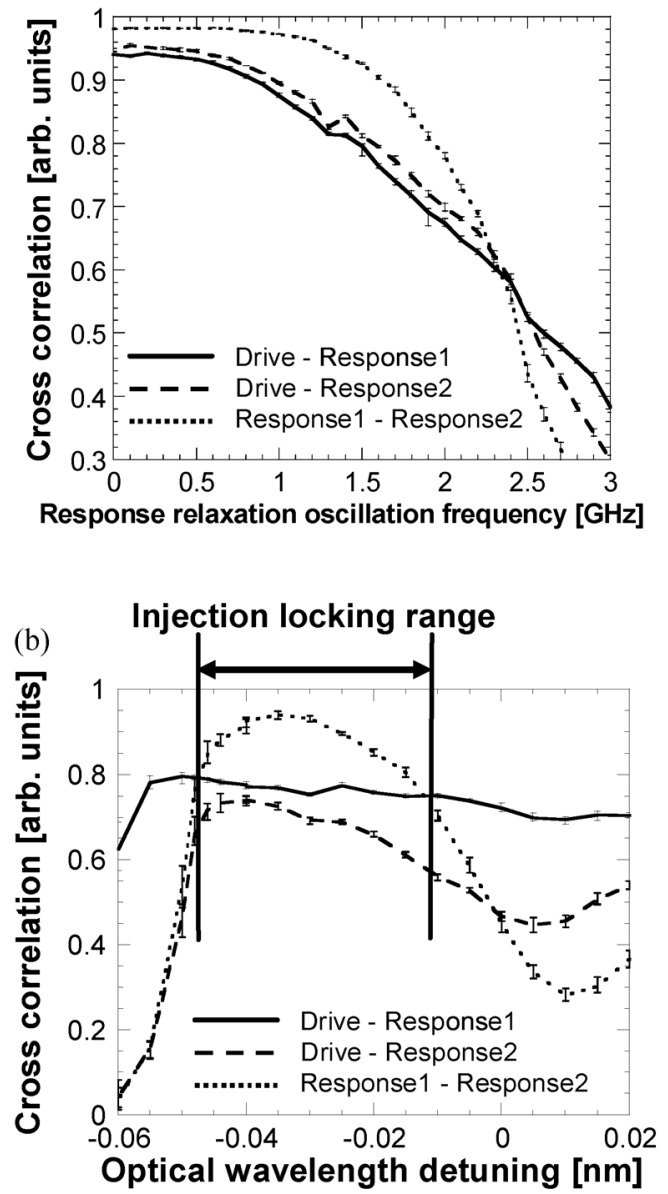

Fig. 8. Experimental result of the cross correlation between a pair of two lasers as a function of (a) the relaxation oscillation frequency of the Response lasers and (b) the optical wavelength detuning between Drive and Response lasers. Solid curve: Drive and Response 1, dashed curve: Drive and Response 2, dotted curve: Response 1 and Response 2 (See Ref. (3)).

範囲内において 2 つの Response 間の相関が Drive-Response 間の相関よりも高くなることが分かった。またインジェク ションロッキング範囲内では, Response1-Response2 間と Drive-Response 間との相関差はほぼ一定であった。

最後に半導体レーザを用いた共通信号入力によるカオス 同期に関する我々の実験結果を Fig. 8 に示す。（詳細は参考 文献( 3 )参照)。これより, Fig. 8 の実験結果は Fig. 7 の数值 解析結果と良く一致していることが分かる。このように本 数值計算結果は, 参考文献( 3 )の実験結果を良く説明してい ることが明らかとなった。

\section{6. むすび}

本研究では半導体レーザにおける共通信号入力によるカ オス同期の数值解析を行った。戻り光を有する半導体レー ザの振る舞いを表す Lang-Kobayashi 方程式を用いて 3 つの レーザ間でインジェクションロッキング型カオス同期を達 
成させた。ここで $2 つ の$ Response 間の緩和発振周波数を一 致させ, Drive と Response 間の緩和発振周波数を一致させな い場合，2つの Response 間の相関が Drive-Response 間の相 関よりも高いことを数值解析により観測した。さらにカオ ス同期のパラメータ依存性について調査し，広い範囲で 2 つの Response 間の相関が Drive-Response 間の相関よりも高 いことが分かった。以上の結果は, 実験結果とも良く一致 した。

\section{謝 辞}

本研究をご支援頂いた，NTT コミュニケーション科学基 礎研究所の外村佳伸所長, 上田修功博士, 牧野昭二博士, 三好正人博士に深く感謝する。また本研究は，文部科学省 科学研究費補助金若手研究（B）および（財）テレコム先端 技術研究支援センターのご支援により行われた。

(平成 19 年 9 月 4 日受付, 平成 19 年 12 月 10 日再受付)

\section{文献}

(1) U. M. Maurer : "Secret key agreement by public discussion from common information”, IEEE Trans. Information Theory, Vol.39, pp.733-742 (1993)

(2) J. Muramatsu, K.Yoshimura, K. Arai, and P. Davis : "Secret Key Capacity for Optimally Correlated Sources Under Sampling Attack", IEEE Trans. Information Theory, Vol.52, No.11, pp.5140-5151 (2006)

( 3 ) T. Yamamoto, I. Oowada, H. Yip, A. Uchida, S. Yoshimori, K. Yoshimura, J. Muramatsu, S. Goto, and P. Davis : "Common-chaotic-signal induced synchronization in semiconductor lasers", Optics Express, Vol.15, No.11, pp.3974-3980 (2007)

(4) H. D. I. Abarbanel, N. F. Rulkov, and M. M. Sushchik : "Generalized synchronization of chaos: The auxiliary system approach”, Phys. Rev. E, Vol.53, pp.4528-4535 (1996)

( 5 ) R. Toral, C. R. Mirasso, E. Hernandez-Garcia, and O. Piro : "Analytical and numerical studies of noise-induced synchronization of chaotic systems", Chaos, Vol.11, pp.665-673 (2001)

(6) A. Uchida, K. Higa, T. Shiba, S. Yoshimori, F. Kuwashima, and H. Iwasawa : "Generalized synchronization of chaos in He-Ne lasers", Phys. Rev. E, Vol.68, pp.016215-1-016215-7 (2003)

(7) A. Uchida, R. McAllister, R. Meucci, and R. Roy : "Generalized synchronization of chaos in identical systems with hidden degrees of freedom", Phys. Rev. Lett., Vol.91, pp.174101-1-174101-4 (2003)

(8) A. Uchida, N. Shibasaki, S. Nogawa, and S. Yoshimori : "Transient characteristics of chaos synchronization in a semiconductor laser subject to optical feedback", Phys. Rev. E, Vol.69, pp.056201-1-056201-9 (2004)

(9) J. Ohtsubo : "Semiconductor Lasers, -Stability, Instability and Chaos-", Springer Verlag, Berlin, Germany (2006)

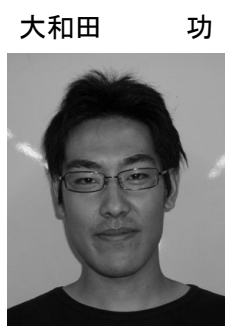

（非会員） 1984 年 5 月 29 日生。 2007 年 3 月拓 殖大学工学部情報エレクトロニクス学科卒業。 現在拓殖大学大学院工学研究科電子情報工学 専攻。
(非会員) 1984 年 12 月 12 日生。 2007 年 3 月 拓殖大学工学部情報エレクトロニクス学科卒 業。現在横河電子機器 (株)。

内田 淳 史 (正員) 1972 年 9 月 25 日生。1995 年慶應義

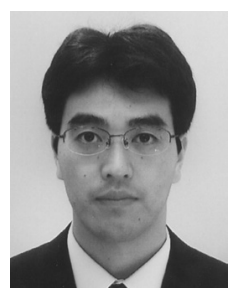
塾大学理工学部電気工学科卒業, 1997 年同大学 院修士課程修了, 2000 年同大学院博士課程修 了。博士 (工学)。2000 年拓殖大学工学部情報 エレクトロニクス学科助手。2001 2002 年 (株) 国際電気通信基礎技術研究所（ATR）適応コミ ユニケーション研究所客員研究員。2002 2004 年アメリカ合衆国メリーランド大学カレッジ パーク校客員研究員 (日本学術振興海外特別研究員)。2005 年拓殖 大学工学部情報エレクトロニクス学科専任講師, 現在に至る。レー ザカオスを用いた超高速暗号鍵共有方式, 物理乱数生成, 符号分割 多重通信, および光秘匿通信に従事。また非線形システムにおける コンシステンシーとカオス同期現象の解明や, 非線形力学理論に基 づく光デバイス開発に従事。応用物理学会, 電子情報通信学会, レ 一ザー学会, 日本物理学会, 米国光学会 (OSA), 米国物理学会 (APS), IEEE 各会員。

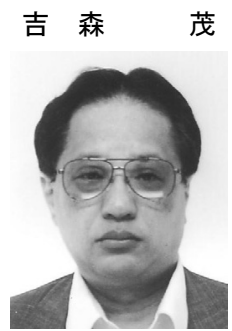

（正員） 1955 年 7 月 17 日生。1978 年東京工 業大学工学部卒業, 1980 年同大学院修士課程修 了。1983 年同大学院博士課程修了。工学博士。 1983 年東京工業大学工学部助手。1989 年拓殖 大学工学部電子工学科助教授。1999 年拓殖大学 工学部情報エレクトロニクス学科教授, 2007 年拓殖大学工学部電子システム工学科教授, 現 在に至る。超伝導エレクトロニクスおよびレー ザカオスの研究に従事。応用物理学会, 電子情報通信学会各会員。

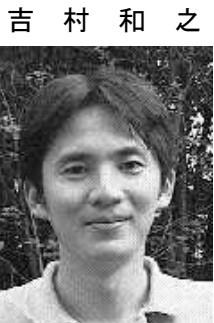

（非正員） 1969 年 2 月 27 日生。1992 年京都大 学工学部物理工学科卒業, 1994 年東京大学大学 院工学研究科航空宇宙工学専攻修士課程修了, 1997 年京都大学大学院工学研究科数理工学専 攻博士課程修了(博士 (工学) 取得)。1997 年日 本電信電話（株）NTT コミュニケーション科学 基礎研究所入社。2001-2002 年カリフォルニア 大学サンディエゴ校客員研究員。現在 NTT コ ミュニケーション科学基礎研究所メディア情報研究部信号処理研 究グループ主任研究員。非線形システムの同期現象，レーザによる 相関乱数を用いた秘密鍵共有方式, 非線形局在波動, 非可積分保存 力学系の研究に従事。日本物理学会, 電子情報通信学会, 応用数理 学会, 航空宇宙学会各会員。 


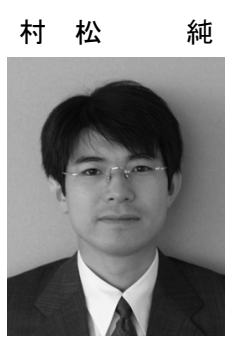

純 (非正員) 1967 年 2 月 2 日生。1990 年名古屋 大学理学部数学科卒業, 1992 年名古屋大学大学 院理学研究科数学専攻博士前期課程修了, 1998 年名古屋大学大学院人間情報学研究科博士 (学 術) 取得。1992 年日本電信電話 (株) 入社。 2007 年-2008 年チューリヒ工科大学客員研究員。現 在 NTT コミュニケーション科学基礎研究所メ ディア情報研究部信号処理研究グループ研究 主任。情報理論の研究に従事。情報理論とその応用学会, 電子情報 通信学会, IEEE 各会員。

後 藤 振一郎 (非正員) 2003 年 3 月名古屋大学大学院理学研

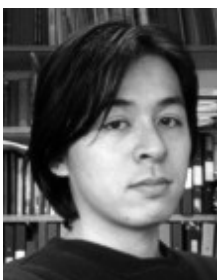
究科物質理学専攻博士課程修了 (博士 (理学) 取得)。2006 年日本電信電話（株）NTT コミュ ニケーション科学基礎研究所。現在ランカスタ 一大学物理学科数理物理グループ。日本物理学 会会員。
Peter Davis （非会員）1958 年 11 月 1 日生。1980 年クイン ズランド大学理学部卒業。1981〜1983 年京都大 学部理学部留学。1987 年クインズランド大学理 学部大学院博士課程修了。1987年～1996 年(株) エイ・ティ・アール光電波通信研究所, 1996 年～2001 年（株）エイ・ティ・アール環境適応 通信研究所, 2001 年 2006 年（株）国際電気 通信基礎技術研究所（ATR）適応コミュニケー ション研究所。2006 年〜同研究所客員研究員。2004 年〜NTT コミ ユニケーション科学基礎研究所招聘研究員 (カオス情報処理オープ ンラボ統括)。コミュニケーションシステムのダイナミックスに関 する研究に従事。ATR Fellow。IEEE 会員。 